\title{
KEVALIDAN DAN RESPON E-MODUL INTERAKTIF BERBASIS APLIKASI ANDROID PADA SISWA KELAS XI SMA NEGERI 4 MUSI RAWAS
}

\author{
Ayu Angraena ${ }^{1}$, Wahyu Arini ${ }^{2}$ \\ ayuangraena@gmail.com \\ ${ }^{1,2}$ Program Studi Pendidikan Fisika STKIP PGRI Lubuklinggau, Sumatera Selatan, Indonesia
}

Received: 30 November 2021

Revised: 3 Desember 2021

Accepted: 15 Desember 2021

\begin{abstract}
This study aims to develop an Android Application-Based Interactive E-Module to Increase Interest and Learning Outcomes of Physics Students of Class XI SMA Negeri 4 Musi Rawas which is valid, practical and effective. This type of research is research and development $(R \& D)$ with the development model used, namely ADDIE (analysis, design, development, implementation, and evaluation). The research sample or research subjects were students of class XI SMA Negeri 4 Musi Rawas students who were taken by simple random sampling technique. Data was collected by using questionnaires and tests. The validation carried out got results in a very good category, with a total score of 176. Student responses to the android application-based e-module were with a score of 88.23 which obtained a score of strongly agree. So it can be said that the interactive e-module based on the android application that was developed was valid and practical.
\end{abstract}

\begin{abstract}
Abstrak: Penelitian ini bertujuan untuk mengetahui kevalidan dan respon siswa terhadap E-Modul Interaktif Berbasis Aplikasi Android. Jenis penelitian ini yaitu research and development $(R \& D)$ dengan model pengembangan yang digunakan yaitu ADDIE (analysis, design, development, implementation, and evalution). Sampel penelitian atau subjek penelitian adalah siswa kelas XI SMA Negeri 4 Musi Rawas siswa yang diambil dengan teknik simple random sampling. Pengumpulan data dilakukan dengan teknik angket dan tes. Validasi yang dilakukan mendapatkan hasil dengan kategori sangat baik yaitu dengan skor total 176. Respon siswa terhadap e-modul berbasis aplikasi android yaitu dengan skor 88,23 yang memperoleh skor sangat setuju. Sehingga dapat di simpulkan bahwa e-modul interaktif berbasis aplikasi android yang dikembangkan telah valid dan praktis.
\end{abstract}

Kata kunci : Aplikasi Android, E-Modul, Pengembangan.

\section{PENDAHULUAN}

Indonesia merupakan salah satu Negara maju dan harus mampu bersaing di era 4.0.

Diera 4.0 ini, Indonesia harus didukung oleh pendidikan yang bermutu. Menurut Salahudin (2011) pendidikan adalah upaya sadar dan sistematis yang dilakukan untuk membina, memotivasi, membantu dan membimbing seseorang untuk mengembangkan semua bakat sehingga dapat mencapai kualitas diri yang lebih baik. Dengan pendidikan, Negara Indonesia akan menghasilkan generasi-generasi ataupun tenaga-tenaga yang berkualitas yang berguna untuk memajukan kehidupan bangsa. Jika ditinjau dari kondisi pendidikan, pendidikan di Indonesia masih sangat memprihatinkan dan tertinggal jauh dari Negara-negara maju lainnya. Terutama pada daerah-daerah tertinggal contohnya Puplished at https://ojs.stkippgri-lubuklinggau.ac.id/index.php/SJPIF 
pendesaan, di daerah pendesaaan baik sarana maupun prasarananya sangatlah minim. Hal ini merupakan salah satu masalah yang sedang dihadapi oleh Negara Indonesia. Pada zaman modern ini, salah satu upaya yang dilakukan untuk meningkatkan mutu pendidikan yaitu dengan menggunakan teknologi. Ilmu pengetahuan dan teknologi mengalami kemajuan yang sangat pesat dari zaman ke zaman, sehingga manusia sangat tergantung dengan teknologi. Dengan demikian, seorang pendidik dituntut untuk memanfaatkan teknologi dalam kegiatan pembelajaran.

Berdasarkan hasil observasi di SMA Negeri 4 Musi Rawas untuk mendapatkan analisa kebutuhan atau analyze, dimulai dengan wawancara guru fisika dan tiga orang siswa dengan kemampuan yang berbeda-beda. Dari hasil wawancara dengan guru diperoleh bahwa pada saat ulangan harian memperoleh 11 siswa yang memiliki nilai di atas KKM sedangkan 17 orang dibawah KKM sehingga mendapatkan rata-rata siswa yang tuntas dalam mengikuti ulangan harian adalah 39,5\% siswa yang memenuhi syarat kriteria ketuntasan maksimal yakni 75 sedangkan sisanya masih dibawah kriteria ketuntasan maksimal. Hal tersebut dikarenakan pemahaman konsep siswa terhadap mata pelajaran fisika masih minim. Saat ini SMA Negeri 4 Musi Rawas sudah menerapkan kurikulum 2013 sedangkan kurikulum 2013 menuntut siswa untuk lebih semangat. Namun, kenyataannya minat belajar fisika siswa masih kurang dan masih banyak materi yang sulit bagi mereka.

Pada saat ini teknologi komunikasi telah merubah wajah dunia. Salah satu inovasi teknologi pendidikan yakni pengembangan media pembelajaran. Media pembelajaran yang penting di era 4.0 adalah media pembelajaran interaktif yang dapat diakses oleh guru maupun siswa melalui smartphone. Baik siswa maupun guru pada saat ini adalah generasi melenial yang selalu menggunakan smartphone dalam kehidupan sehari-hari. Pada zaman sekarang setiap orang selalu bergantung dengan yang namanya smartphone. Dengan menggunakan smartphone sebagai media pembelajaran itu akan dapat mempermudah siswa untuk belajar dimanapun dan kapanpun siswa ingin belajar. Media pembelajaran harus dapat digunakan di berbagai tempat, secara keseluruhan dan mudah diperbanyak Arsyad (dalam Pratama, 2011).

Berdasarkan fakta yang terjadi di zaman milenial ini dapat disimpulkan banyak siswa yang mengalami kesulitan dalam belajar terkhususnya pada mata pelajaran fisika serta masih banyak siswa yang belum bisa memanfaatkan teknologi dengan baik. Sebagai 
seorang guru kita harus bisa menciptakan sesuatu hal yang baru dengan memanfaatkan teknologi dan sebagai seorang guru kita juga harus bisa menciptakan sebuah media pembelajaran yang efektif seperti media pembelajaran berbasis aplikasi android yang dapat digunakan untuk proses pembelajaran sehingga dapat membuat siswa menjadi lebih aktif, semangat dan mandiri untuk mendapatkan informasi. Apalagi kondisi kita pada saat ini yakni semua kegiatan harus dilakukan dari rumah termasuk sekolah, sekarang siswa melakukan kegiatan belajar mengajar dari rumah. Media pembelajaran berbasis android merupakan media pembelajaran yang sangat cocok untuk digunakan. Melihat kondisi sekarang ditengah pandemi maka penelitian yang akan dilakukan oleh peneliti nanti akan dilakukan secara daring proses pembelajarannya sedangkan evaluasinya akan dilakukan secara tatap muka. Media pembelajaran berbasis android perlu dikembangkan mengingat banyak peserta didik belajar mandiri dan mengakses tugas sekolah maupun web sekolah dengan menggunakan smartphone. Perkembangan media pembelajaran dengan teknologi dapat mendorong terjadinya perpaduan antara teknologi cetak dan teknologi komputer dalam kegiatan pembelajaran, sehingga modul dapat ditransformasikan penyajiannya ke dalam bentuk elektronik atau e-modul (Irawati, A. E., \& Setyadi, D, 2021).

Melihat kondisi tersebut peneliti melakukan pengembangan media pembelajaran berbasis aplikasi android, dimana pengembangan media ini sudah dilakukan oleh peneliti sebelumnya namun berbeda dengan pengembangan media pembelajaran interaktif yang akan dikembangkan oleh peneliti pada penelitian ini, pada penelitian ini peneliti mengembangkan media pembelejaran berbasis digital dimana teknologi informasi itu menyediakan konten audio, visual maupun audiovisual, yang mana aplikasi android ini tidak hanya memuat materi pembelajaran berbentuk teks saja, namun juga berbentuk gambar dan video pembelajaran serta dilengkapi dengan contoh soal dan animasi-animasi bergerak dengan itu akan membuat media pembelajaran tersebut tidak monoton sehingga mempermudah siswa dalam memahami materi pembelajaran dan menumbuhkan minat belajar siswa dalam belajar. Jika minat belajar pada siswa meningkat maka diharapkan hasil belajar yang didapatkan oleh siswa dapat meningkat juga.

Dalam penelitian dikembangkan suatu media pembelajarn yang berupa e-modul interaktif berbasis aplikasi android. Pemilihan media yang tepat tentu sangat berpengaruh terhadap berhasil tidaknya sebuah proses belajar mengajar. Hal ini tentu karena pada 
proses belajar mengajar membutuhkan rasa suka dari diri siswa sebagai peserta didik. Rasa suka sendiri dapat dimunculkan dari ketertarikan siswa terhadap media pembelajaran yang menarik bagi mereka. Jika merujuk pada perkembangan teknologi informasi saat ini, tentu media pembelajaran harus juga dapat beradaptasi dengan perkembangan tersebut (Restu, I. A., \& Arini, W, 2020). Modul sebagai salah satu media pembelajaran juga harus menyesuaikan, salah satu caranya dengan menggunakan modul elektronik (e-module). Modul adalah salah satu bahan ajar yang dapat dimanfaatkan siswa secara mandiri, serta dapat digunakan kapanpun dan dimanapun sesuai dengan kebutuhan dari siswa. Modul yang diberikan oleh sekolah saat ini kebanyakan masih dalam bentuk cetak. Sedangkan teknologi telah mengalami perkembangan, bahkan telah memberikan dampak positif bagi dunia pendidikan. Sehingga dengan adanya perkembangan teknologi dapat dimanfaatkan dengan menjadikan modul tersebut menjadi modul yang berbasis elektronik seperti e-modul (Auliya, M., \& Nurmawati, I, 2021). Media pembelajaran E-modul disebut media belajar mandiri karena didalamnya dilengkapi dengan petunjuk untuk belajar sendiri (mandiri), sehingga pembelajar dapat melakukan kegiatan pembelajaran tanpa kehadiran pengajar secara langsung (Kuncahyono, 2018).

\section{METODE PENELITIAN}

Menurut Saputro (2016) metode Research \& Development $(R \& D)$ merupakan metode penelitian yang mendapatkan sebuah produk dalam bidang keahlian tertentu, yang diikuti produk sampingan tertentu serta memiliki efektifitas dari sebuah produk tersebut. Menurut Hamzah (2019) model pengembangan ADDIE (Analysis-DesaignDevelop-Implement-Evaluate) merupakan model pembelajaran yang berorientasi dikelas, dimana model pengembangan ini ada beberapa tahapan yakni : (1) analisa, (2) perancangan, (3) pengembangan, (4) Implementasi, (5) evaluasi. Adapun bagian langkahlangkah model pengembangan ADDIE dapat dilihat seperti gambar 1. 


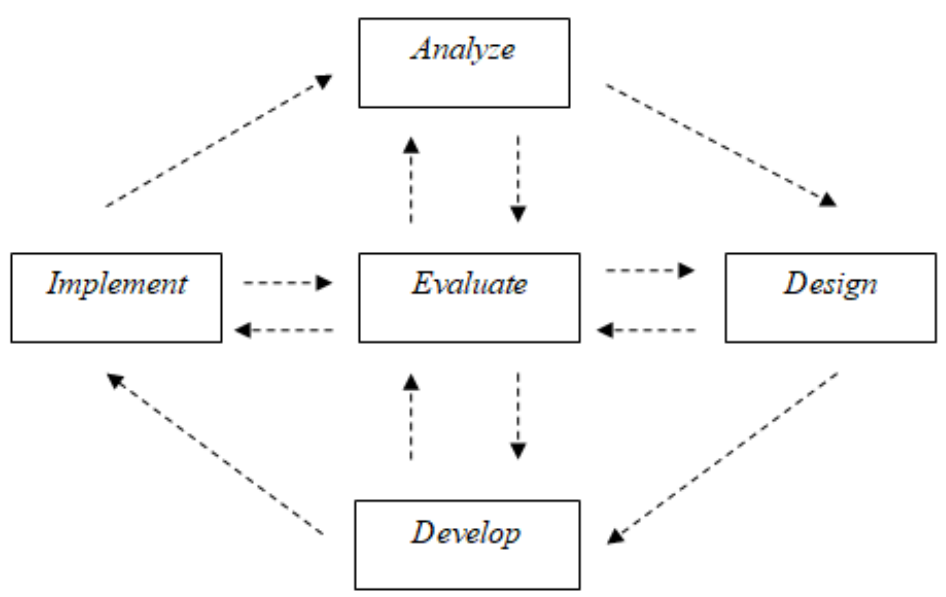

Gambar 1. Langkah Model Pengembangan Perangkat Pembelajaran ADDIE (Sumber: Tegeh, 2014)

Model pengembangan ADDIE merupakan model pengembangan yang mucul pada tahun 1990-an yang dikembangkan oleh Mollenda dan Raiser. Model pengembangan ini adalah model pengembangan yang bersifat generik yang berfungsi sebagai pedoman dalam membuat perangkat dan infrastruktur program yang dinamis, efektif serta mendukung kinerja program itu sendiri. Model pengembangan ini memiliki 5 langkah yakni antara lain : Analysis, Desaign, Development, Implementation Dan Evalution (Rahman, 2013:210). Dalam penelitian pengembangan ini menggunakan model pengembangan ADDIE yang dilakukan hingga tahap evaluasi formatif saja dikarenakan keterbatasan waktu biaya dan peneliti itu sendiri jadi hanya dilakukan sampai tahap evaluasi formatif saja. Dalam $e$-modul berupa $e$-modul interaktif berbasis aplikasi android dengan metode penelitian Research and Development (R\&D) yang menggunakan teknik pengumpulan data dan teknik analisis data yaitu sebagai berikut:

1. Teknik Pengumpulan Data

a. Angket Kepraktisan

Menurut Mulyatiningsih (2014:28) Angket atau kuesioner merupakan alat pengumpulan data yang memuat sejumlah pertanyaan atau pernyataan yang harus dijawab oleh subjek penelitian. Pada penelitian ini menggunakan dua angket yakni angket kepraktisan dan angket minat berikut penjelasan angket yang digunakan dalam penelitian ini. Didalam penelitian ini peneliti menggunakan angket kepraktisan, angket ini digunakan untuk memperoleh data kepraktisan belajar yang dilakukan oleh siswa dan mendukung data yang diperoleh pada saat observasi. Dalam hal ini angket untuk mendapatkan data tentang kelayakan dari media pembelajaran interaktif berbasis aplikasi 
android. Angket tersebut diperuntukkan bagi ahli materi, ahli media, ahli tata bahasa, dan pembelajaran fisika, serta guru fisika. Angket ini juga digunakan untuk melihat respon siswa saat proses uji coba produk dilakukan. Dalam hal ini lembar yang digunakan berupa angket respon siswa yang berisi pertanyaan untuk merlihat respon siswa terhadap media pembelajaran fisika yang dikembangkan. Instrumen ini terlebih dahulu di validasi oleh ahli materi, bahasa dan media, angket yang digunakan untuk melihat respon peserta didik terhadap media pembelajaran yang dikembangkan ini menggunakan lembar angket uji coba. Angket respon kepraktisan ini diberikan pada uji coba kelompok kecil dan pada uji coba kelompok besar. Angket ini nantinya diberikan kepada peserta didik untuk melihat kepraktisan dari e-modul yang dikembangkan oleh peneliti. Jenis angket yang digunakan merupakan jenis angket terbuka, dengan skala yang digunakan dalam angket ini merupakan skala likert tipe 5. Instrumen-instrumen tersebut terlebih dahulu divalidasi oleh dosen ahli dalam bidangnya masing-masing.

\section{Teknik Analisis Data}

Teknik analisis data yang digunakan yaitu deskriptif kuantitatif, analisis data ini dilakukan bertujuan untuk mengetahui kelayakan dan respon siswa terhadap produk yang dikembangkan yakni $e$-modul berbasis aplikasi android untuk meningkatkan minat dan hasil belajar fisika siswa kelas XI SMA Negeri 4 Musi Rawas media yang dikembangkan mengambil materi tentang gelombang bunyi.

a. Analisis Kelayakan dan Respon Siswa Terhadap E-Modul berbasis aplikasi android

Untuk respon siswa terhadap e-modul berbasis aplikasi android dilakukan dengan menganalisis angket atau kuesioner yang diberikan oleh peneliti, lembar kelayakan lembar kerja siswa tersebut dengan menggunakan isntrumen lembar uji coba. Angket ini juga melihat respon siswa saat proses uji coba produk, penyusunan angket telah disusun bersadarkan kisi-kisi instrumen angket yang disusun dengan skala Likert 5 dan menggunakan angket yang telah lebih dulu dikoreksi oleh ahli.

Respon dilihat menggunakan instrumen angket respon siswa tujuan utama angket ini adalah untuk mengetahui respon siswa, dan untuk menentukan kualitas (kepraktisan) dari media pembelajaran yang dikembangkan. Pelaksanaan uji coba kelompok kecil dan uji coba kelompok besar. Menurut Widoyoko (2019) skor yang ditentukan dapat di hitung dengan menggunakan rumusan sebagai berikut:

Tabel 1. Aturan Pemberian Skor Angket Respon KATEGORI SKOR 


\begin{tabular}{ll}
\hline Sangat Kurang & 1 \\
Kurang & 2 \\
Cukup Baik & 3 \\
Baik & 4 \\
Sangat Baik & 5 \\
\hline
\end{tabular}

Untuk penilaian angket tentang respon siswa terhadap media pembelajaran interaktif berbasis aplikasi android. Adapun langkah-langkah analisis rerata dilakukan pada angket kepraktisan sebagai berikut Widoyoko (2019):

1) Menghitung nilai rerata skor tiap butir instrumen.

2) Menghitung nilai rerata skor tiap komponen.

3) Membandingkan nilai rerata skor tiap komponen dengan kriteria.

a) Uji Kelompok Kecil

Widoyoko (2019) menyatakan bahwa skor yang telah ditetapkan dapat dihitung dengan menggunakan rumusan sebagai berikut:

$\begin{array}{ll}\text { Skala } & : 5 \\ \mathrm{X} & : \text { skor aktual (skor yang dicapai) } \\ \bar{x} & : \text { rerata skor ideal } \\ & :\left(\frac{1}{2}\right) \text { (skor tertinggi ideal+skor terendah ideal) } \\ \mathrm{SB}_{\mathrm{i}} & :\left(\frac{1}{2}\right)\left(\frac{1}{3}\right) \text { (skor tertinggi ideal-skor terendah ideal) }\end{array}$

Skor tertinggi ideal : $\sum$ butir kriteria $\mathrm{x}$ skor tertinggi

Skor terendah ideal : $\sum$ butir kriteria x skor terendah

Rentang skor pada masing-masing angket respon dapat diperoleh pada tabel berikut:

Tabel 2. Rentang skor uji kelompok kecil

\begin{tabular}{cccc}
\hline No & Rentang skor (i) & Nilai & Kategori \\
\hline 1 & $\mathrm{X}>\bar{x}+1,80 \mathrm{Sb} i$ & $\mathrm{~A}$ & Sangat baik \\
2 & $\bar{x}+0,60 \mathrm{SB} i<\mathrm{X} \leq \overline{\mathrm{x}}+1,80 \mathrm{SB} i$ & $\mathrm{~B}$ & Baik \\
3 & $\bar{x}-0,60 \mathrm{SB} i<\mathrm{X} \leq \overline{\mathrm{x}}+0,60 \mathrm{SB} i$ & $\mathrm{C}$ & Cukup baik \\
4 & $\bar{x}-1,80 \mathrm{SB} i<\mathrm{X} \leq \overline{\mathrm{x}}-0,60 \mathrm{SB} i$ & $\mathrm{D}$ & $\begin{array}{c}\text { Kurang } \\
\text { baik }\end{array}$ \\
5 & $\mathrm{X} \leq \overline{\mathrm{x}}-1,80 \mathrm{SB} i$ & $\mathrm{E}$ & $\begin{array}{c}\text { Sangat } \\
\text { kurang baik }\end{array}$ \\
\hline
\end{tabular}

$$
\begin{aligned}
& \bar{x}=\frac{\sum X}{n} \\
& \text { Keterangan : } \\
& \bar{x} \quad=\text { Skor rata-rata } \\
& \sum X=\text { jumlah skor } \\
& n \quad=\text { jumlah penilai }
\end{aligned}
$$


b) Uji Kelompok Besar

Widoyoko (2019:236) menyatakan bahwa skor yang telah ditetapkan dapat dihitung dengan menggunakan rumusan sebagai berikut:

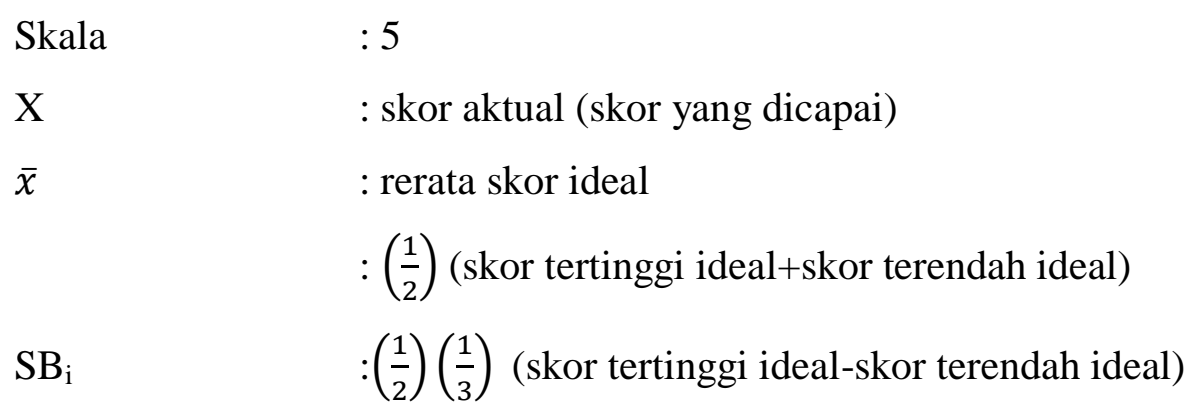

Skor tertinggi ideal : $\sum$ butir kriteria $\mathrm{x}$ skor tertinggi

Skor terendah ideal : $\sum$ butir kriteria x skor terendah

Rentang skor pada masing-masing angket respon dapat diperoleh pada tabel berikut:

Tabel 3. Rentang skor uji kelompok besar

\begin{tabular}{cccc}
\hline No & Rentang skor (i) & Nilai & Kategori \\
\hline 1 & $\mathrm{X}>\bar{x}+1,80 \mathrm{Sb} i$ & $\mathrm{~A}$ & Sangat baik \\
2 & $\bar{x}+0,60 \mathrm{SB} i<\mathrm{X} \leq \overline{\mathrm{x}}+1,80 \mathrm{SB} i$ & $\mathrm{~B}$ & Baik \\
3 & $\bar{x}-0,60 \mathrm{SB} i<\mathrm{X} \leq \overline{\mathrm{x}}+0,60 \mathrm{SB} i$ & $\mathrm{C}$ & Cukup baik \\
4 & $\bar{x}-1,80 \mathrm{SB} i<\mathrm{X} \leq \overline{\mathrm{x}}-0,60 \mathrm{SB} i$ & $\mathrm{D}$ & $\begin{array}{c}\text { Kurang } \\
\text { baik }\end{array}$ \\
5 & $\mathrm{X} \leq \overline{\mathrm{x}}-1,80 \mathrm{SB} i$ & $\mathrm{E}$ & $\begin{array}{c}\text { Sangat } \\
\text { kurang baik }\end{array}$ \\
\hline
\end{tabular}

$$
\begin{aligned}
& \bar{x}=\frac{\sum X}{n} \\
& \text { Keterangan : } \\
& \bar{x} \quad=\text { Skor rata-rata } \\
& \sum X=\text { jumlah skor } \\
& n \quad=\text { jumlah penilai }
\end{aligned}
$$

\section{HASIL DAN PEMBAHASAN}

\section{A. Hasil Penelitian}

\section{Validasi Materi}

Kualitas kelayakan e-modul interaktif berbasis aplikasi android pada materi gelombang bunyi melalui tahapan evaluasi ahli materi yang bertujuan untuk melihat kevalidan materi $e$-modul yang dikembangkan. Evaluasi tersebut dilakukan oleh ahli materi yakni Ibu Endang Lovisia, M.Pd.Si sebagai dosen program studi pendidikan fisika dan guru fisika kelas XI yakni Ibu Afrihesty Suzima, S.Pd. 
Tabel 4. Hasil Perhitungan Ahli Materi Dosen Fisika

\begin{tabular}{cccc}
\hline No & Rentang skor (i) & Nilai & Kategori \\
\hline 1 & $\mathrm{X}>50,4$ & A & Sangat Valid \\
2 & $40,8<\mathrm{X} \leq 50,4$ & $\mathrm{~B}$ & Valid \\
3 & $31,2<\mathrm{X} \leq 40,8$ & $\mathrm{C}$ & Cukup Valid \\
4 & $21,6<\mathrm{X} \leq 31,2$ & $\mathrm{D}$ & Tidak Valid \\
5 & $\mathrm{X} \leq 21,6$ & $\mathrm{E}$ & Sangat Tidak Valid \\
\hline
\end{tabular}

Berdasarkan hasil validasi di atas terdapat 12 butir pertanyaan diperoleh dari aspek materi. Hasil validasi ahli materi adalah 50 dengan 12 indikator sehingga diperoleh kritik dan saran adalah sesuaikan lagi antara topik bahasan pada materi yang ada di media pembelajaran. Dengan demikian hasil penilaian validator ahli materi termasuk dalam kriteria Sangat Valid.

Tabel 5. Hasil Perhitungan Ahli Materi Guru Fisika

\begin{tabular}{cccc}
\hline No & Rentang skor (i) & Nilai & Kategori \\
\hline 1 & $\mathrm{X}>50,4$ & A & Sangat Valid \\
2 & $40,8<\mathrm{X} \leq 50,4$ & $\mathrm{~B}$ & Valid \\
3 & $31,2<\mathrm{X} \leq 40,8$ & $\mathrm{C}$ & Cukup Valid \\
4 & $21,6<\mathrm{X} \leq 31,2$ & $\mathrm{D}$ & Tidak Valid \\
5 & $\mathrm{X} \leq 21,6$ & $\mathrm{E}$ & Sangat Tidak Valid \\
\hline
\end{tabular}

Berdasarkan hasil validasi di atas terdapat 12 butir pertanyaan diperoleh dari aspek materi. Hasil validasi ahli materi adalah 50 dengan 12 indikator. Dengan demikian hasil penilaian validator ahli materi termasuk dalam kriteria Sangat Valid.

2. Validasi Media

Kualitas kelayakan e-modul interaktif berbasis aplikasi android pada materi gelombang bunyi melalui tahapan evaluasi ahli media yang bertujuan untuk melihat kevalidan media pada e-modul yang dikembangkan. Evaluasi tersebut dilakukan oleh ahli media yakni dosen STKIP-PGRI Lubuklinggau yang ahli pada bidang media yakni Bapak Leo Charli.

Tabel 6. Hasil Perhitungan Ahli Media

\begin{tabular}{cccc}
\hline No & Rentang skor (i) & Nilai & Kategori \\
\hline 1 & $\mathrm{X}>42,06$ & A & Sangat Valid \\
2 & $34,02<\mathrm{X} \leq 42,06$ & B & Valid \\
3 & $25,98<\mathrm{X} \leq 34,02$ & C & Cukup Valid \\
4 & $17,94<X \leq 25,98$ & D & Tidak Valid \\
5 & $X \leq 17,94$ & E & Sangat Tidak Valid \\
\hline
\end{tabular}


Berdasarkan hasil validasi di atas terdapat 10 butir pertanyaan diperoleh dari aspek media. Hasil validasi ahli media adalah 46 dengan 10 indikator sehingga diperoleh kritik dan saran adalah media pembelajaran berbasis aplikasi android dapat digunakan tanpa revisi. Dengan demikian hasil penilaian validator ahli media termasuk dalam kriteria Sangat Valid. Sangat valid diartikan bahwa menurut ahli media yang dikembangkan sudah layak untuk digunakan pada tahap selanjutnya.

3. Validasi Bahasa

Kualitas kelayakan e-modul interaktif berbasis aplikasi android pada materi gelombang bunyi melalui tahapan evaluasi ahli media yang bertujuan untuk melihat kevalidan media pada e-modul yang dikembangkan. Evaluasi tersebut dilakukan oleh ahli bahasa yakni dosen Bahasa Indonesia STKIP-PGRI Lubuklinggau yakni Bapak Agung Nugroho.

Tabel 7. Hasil Perhitungan Validasi Bahasa

\begin{tabular}{cccc}
\hline No & Rentang skor (i) & Nilai & Kategori \\
\hline 1 & $\mathrm{X}>25,2$ & A & Sangat Valid \\
2 & $22,6<\mathrm{X} \leq 25,2$ & $\mathrm{~B}$ & Valid \\
3 & $15,6<\mathrm{X} \leq 22,6$ & $\mathrm{C}$ & Cukup Valid \\
4 & $10,8<\mathrm{X} \leq 15,6$ & $\mathrm{D}$ & Tidak Valid \\
5 & $\mathrm{X} \leq 10,8$ & E & Sangat Tidak Valid \\
\hline
\end{tabular}

Berdasarkan hasil validasi di atas terdapat 6 butir pertanyaan diperoleh dari aspek bahasa. Hasil validasi ahli bahasa adalah 26 dengan 6 indikator sehingga diperoleh kritik dan saran adalah perhatikan penulisan (sesuai dengan EYD) menggunakan kata depan diperhatikan kembali. Dengan demikian hasil penilaian validator ahli bahasa termasuk dalam kriteria Sangat Valid.

Penelitian Dahlan (2016) melaporkan bahwa e-modul pada materi sistem peredaran darah yang valid dan praktis dapat membantu siswa dalam memahami materi. Adanya animasi-animasi dan video dapat menambah minat siswa dalam belajar sehingga memberikan pengalaman belajar yang nyata dan menarik. Emodul juga telah banyak dikembangkan yang telah diuji kevalidan dan kepraktisannya. Sepriandi, dkk (2016) tentang pengembangan LKS dengan pendekatan saintifik berbasis discovery learning pada materi asam basa untuk pembelajaran kimia kelas XI SMA/MA bahwa Validitas dan praktikalitas LKS tersebut sangat tingi. Penelitian yang dilakukan oleh Jannah, dkk (2017) tentang pengembangan media pembelajaran asam basa menggunakan aplikasi android 
berbasis chemistry triangle KELAS XI SMA/MA bahwa media yang dihasilkan memiliki kevalidan dan kepraktisan yang sangat tinggi.

4. Angket Kepraktisan pada kelompok Kecil

Pada pengembangan $e$-modul interaktif berbasis aplikasi android ini terdiri atas pelaksanaan uji kelompok kecil. Uji coba kelompok kecil dilakukan kepada 9 orang siswa dikelas XI. Pada uji coba kelompok kecil peneliti memberi angket respon dan angket minat yang bertujuan untuk melihat respon siswa terhadap produk yang dikembangkan dan minat belajar fisika setelah menggunakan e-modul yang dikembangkan. Kepraktisan adalah tingkat kemudahan penggunaan e-modul dalam proses pembelajaran. Kepraktisan emodul dalam penelitian ini didasarkan dari angket respon peserta didik. Setelah e-modul yang dikembangkan telah dinilai dan dinyatakan layak oleh validator, maka langkah selanjutnya adalah memperoleh respon siswa. Respon siswa penting dilakukan karena untuk menentukan kelayakan dan ketertarikan terkait perangkat yang dikembangkan dari aspek pengguna belajar (Hamzah \& Mentari, 2017). Angket respon disebarkan setelah proses pembelajaran selesai. Peserta didik diminta mengisi angket sesuai pendapatnya masing-masing berdasarkan pengalaman yang dialaminya selama kegiatan pembelajaran menggunakan e-modul (Muzijah, R., Wati, M., \& Mahtari, S, 2020). Hasil angket respon dan angket minat pada uji coba kelompok kecil dapat dilihat sebagai berikut:

Tabel 8. Rentang Skor

\begin{tabular}{cccc}
\hline No & Rentang skor (i) & Nilai & Kategori \\
\hline 1 & $\mathrm{X}>42,006$ & $\mathrm{~A}$ & Sangat Setuju \\
2 & $34,002<\mathrm{X} \leq 42,006$ & $\mathrm{~B}$ & Setuju \\
3 & $25,998<\mathrm{X} \leq 34,002$ & $\mathrm{C}$ & Cukup Setuju \\
4 & $17,994<\mathrm{X} \leq 25,998$ & $\mathrm{D}$ & Tidak Setuju \\
5 & $\mathrm{X} \leq 17,994$ & $\mathrm{E}$ & Sangat Tidak \\
& & & Setuju \\
\hline
\end{tabular}

Berdasarkan hasil angket uji kelompok kecil yang diperoleh, dapat disimpulkan bahwa respon siswa terhadap e-modul berbasis aplikasi android adalah Sangat Setuju dengan skor rata-rata 45,4.

5. Angket Kepraktisan pada Kelompok Besar

Uji coba kelompok besar dilakukan pada satu kelas yakni XI IPA 2 SMA Negeri 4 Musi Rawas yang dipilih dengan teknik Simple Random Sampling. Uji coba kelompok besar bertujuan untuk melihat kepraktisan dari media pembelajaran 
yang dikembangkan. Pada uji coba kelompok besar peneliti memberikan angket respon untuk melihat kepraktisan. Berikut hasil angket kepraktisan siswa terhadap e-modul interaktif yang dikembangkan yakni dapat dilihat pada tabel 7:

Tabel 9. Perhitungan Respon Peserta Didik

\begin{tabular}{cccc}
\hline No & Rentang skor (i) & Nilai & Kategori \\
\hline 1 & $\mathrm{X}>88,2$ & A & Sangat Setuju \\
2 & $71,4<\mathrm{X} \leq 88,2$ & $\mathrm{~B}$ & Setuju \\
3 & $54,6<\mathrm{X} \leq 71,4$ & $\mathrm{C}$ & Cukup Setuju \\
4 & $37,8<\mathrm{X} \leq 54,6$ & $\mathrm{D}$ & Tidak Setuju \\
5 & $\mathrm{X} \leq 54,6$ & $\mathrm{E}$ & Sangat Tidak \\
& & & Setuju \\
\hline
\end{tabular}

Jadi, dapat disimpulkan hasil respon terhadap media pembelajaran yang dikembangkan memperoleh 15 siswa mengatakan sangat setuju dan 12 siswa mengatakan setuju sedangkan nilai rata-rata diperoleh sebesar 88,23 dengan kategori sangat setuju, maka dapat dikatakan media pembelajaran yang dikembangkan sangat praktis. Hal ini juga sejalan dengan penelitian yang dilakukan oleh Fonda \& Sumargiyani (2018) bahwa kuesioner respon siswa yang dikembangkan berdasarkan komponen: 1) kelayakan konten; 2) bahasa; 3) presentasi; 4) kegrafikan. Kemudian data yang diperoleh dari respon siswa diubah menjadi nilai kualitatif berdasarkan kriteria penilaian ideal sehingga diperoleh skor rata-rata respons siswa adalah 86,44 . Hal ini didukung oleh penelitian sebelumnya yang dilakukan oleh Faizah dan Munoto (dalam Misbah dkk, 2018) yang menjelaskan bahwa media pembelajaran yang dikembangkan juga berkategorikan sangat praktis berdasarkan penilaian siswa dan keterlaksanaan pembelajaran. Media dikatakan praktis jika telah memenuhi syarat dalam memudahkan siswa dalam proses pembelajaran baik dalam maupun diluar kelas (Rizki dan Apsari, 2018).

Sehingga dapat disimpulkan bahwa angket tergolong praktis ketika digunakan oleh peserta didik hal ini terjadi karena adanya kelebihan yang dimiliki oleh emodul tersebut. Kelebihan yang dirasakan yaitu emodul ini berbentuk aplikasi dimana untuk mengakses isi dari e-modul tidak memerlukan koneksi internet untuk mengunduh aplikasi dan untuk mengaksesnya kembali tidak perlu dihubungkan dengan koneksi internet lagi. E-modul yang dikembangkan telah diberikan kepada peserta didik sebagai fasilitas untuk memudahkan peserta didik dalam 
pembelajaran. Peserta didik mampu mengakses e-modul kapan pun peserta didik inginkan sehingga dapat fleksibel untuk belajar secara mandiri.

\section{SIMPULAN DAN SARAN}

\section{A. Kesimpulan}

Berdasarkan penelitian, peneliti menyimpulkan bahwa:

1. Peneliti melakukan proses pengembangan E-modul berbasis aplikasi android pada materi gelombang bunyi menggunakan model pengembangan ADDIE dengan 5 tahapan yaitu tahap analisis, desain, pengembangan, penyebaran dan evaluasi. Pada penelitian ini hanya melakukan evaluasi formatif saja tidak dilakukan evaluasi sumatif.

2. Hasil penilaian $e$-modul interaktif berbasis aplikasi android untuk meningkatkan minat dan hasil belajar fisika siswa materi gelombang bunyi dikatakan valid, praktis dan efektif.

\section{B. Saran}

Adapun saran pemanfaatan dan pengembangan produk lebih lanjut adalah sebagai berikut:

1. Penulis menyarankan E-modul berbasis aplikasi android dapat digunakan dalam dan membantu guru dalam pembelajaran materi gelombang bunyi karena telah mendapat penilaian sangat baik dan layak digunakan.

2. E-modul berbasis aplikasi android bisa dikolaborasikan dengan model pembelajaran yang lain selama masih menyertakan komponen metode eksperimen.

\section{DAFTAR PUSTAKA}

Auliya, M., \& Nurmawati, I. (2021). Pengembangan E-Modul Materi Pisces Kelas X SMA/MA dengan Konteks Potensi Pesisir Jembrana. Indonesian Journal of Mathematics and Natural Science Education, 2(1), 45-51.

Fonda, A., \& Sumargiyani, S. (2018). The Developing Math Electronic Module With Scientific Approach Using Kvisoft Flipbook Maker Pro for Xi Grade of Senior High School Students. Infinity Journal, 7(2), 109-122.

Hamza, A. (2019) Metode Penelitian \& Pengembangan (Research \& Development). 2nd edn. Malang: CV. Literasi Nusantara Abadi.

Hamzah, I., \& Mentari, S. (2017). Development of Accounting E-Module to Support the Scientific Approach of Students Grade X Vocational High School. Journal of 
Accounting and Business Education, 1(1), 78-88.

Irawati, A. E., \& Setyadi, D. (2021). Pengembangan E-Modul Matematika pada Materi Perbandingan Berbasis Android. Jurnal Cendekia: Jurnal Pendidikan Matematika, 5(3), 3148-3159.

Kuncahyono. (2018). Pengembangan E-Modul (Modul Digital) Dalam Pembelajaran Tematik di Sekolah Dasar. JMIE (Journal of Madrasah Ibtidaiyah Education), 2(2), 219.

Misbah, dkk. (2018). Pengembangan E-Learning Berbasis Schoology pada Materi Implus dan Momentum untuk Melatih Literasi Digital. Jurnal Pancasakti Science Education Journal. 3 (2), 109-115.

Pratama, C. and Arsyad, M. (no date) 'Pengembangan Media Pembelajaran Interaktif Berbasis Aplikasi Android Pada Konsep Sistem Pernapasan Manusia Jenjang SMA', 0417(2).

Rahman, Muhammad \& Amri, S. (2013) Strategi \& Desain Pengembangan Sistem Pembelajaran. Jakarta: Prestasi Pustaka.

Restu, I. A., \& Arini, W. (2020). Pengembangan LKS Fisika Berbasis Contextual Teaching and Learning Materi Suhu dan Kalor Pada Siswa Kelas XI SMA Negeri 6 Lubuklinggau. SILAMPARI JURNAL PENDIDIKAN ILMU FISIKA, 2(2), 92-106.

Riski , S.. \& Apsari, N.P. (2018). Media Pembelajaran Matematika Berbasis Android pada Materi Program Linier. Jurnal FKIP. 7 (1), 168-167.

Salahudin, A. (2011) Filsafat Pendidikan. Cet-10. Bandung: Pustaka Setia.

Sepriandi, P. Ellizar, and Rahadian Zainul. (2018).“. Pengembangan LKS dengan Pendekatan Saintifik Berbasis Discovery Learning Pada Materi Asam Basa untuk pembelajaran Kelas XI SMA/MA”. INA-Rxiv. September, 19.

Tegeh, Dr. I Made, dkk. (2014). Model Penelitian Pengembangan. Yogyakarta: Graha Ilmu.

Widoyoko, E. P. (2019) Evaluasi Program Pembelajaran. x. Edited by S. Z. Qudsy. Yogyakarta: Pustaka Pelajar.

Mulyatiningsih, E. (2014). Metode Penelitian Terapan Bidang Pendidikan. Badung: Alfabeta

Muzijah, R., Wati, M., \& Mahtari, S. (2020). Pengembangan e-modul menggunakan aplikasi Exe-Learning untuk melatih literasi sains. Jurnal Ilmiah Pendidikan Fisika, 4(2), 89-98. 